\title{
Gender in educational and public discourse of the Church. Analysis of the Pastoral Letter on the Feast of the Holy Family
}

\section{KEYWORDS}

discourse, public discourse, Church discourse, religious discourse, educational discourse, gender, language

\begin{abstract}
Kasiak Mateusz, Gender in educational and public discourse of the Church. Analysis of the Pastoral Letter on the Sunday of the Holy Family. Culture - Society - Education no 2(16) 2019, Poznań 2019, pp. 289-312, Adam Mickiewicz University Press. ISSN 2300-0422. DOI 10.14746/ kse.2019.16.19.

Gender as a category of cultural gender and gender identity appears not only in scientific discourse as a topic of research, but also in public discourse, as a subject of various debates and disputes. This concept was also included into the discourse of the Catholic Church. Its creators - church leaders - embarked upon a public reinterpretation of the concept of gender, thus inserting their point of view into the broader political and ideological dispute. The aim of this paper is to review the postulates of the church concerning gender in the Pastoral Letter on the Feast of the Holy Family, which seems to be a leading programme paper concerning this issue. In this paper, gender as a research and scientific category is isolated from the scientific discourse and appropriated by the educational discourse of the church, where it functions as a scare tactic. Structural modifications in the text and style of the letter, stylistic and rhetorical tricks, as well as pragmatic mechanisms, make the text of the pastoral letter a persuasive political argument.
\end{abstract}

The issues of gender and gender identity are not only the subject of scientific research, but also serve as a topic of public comments and debates. The article shows the understanding of gender in the Pastoral Letter on the Feast of the Holy Family. 
This document was not chosen by accident. First of all, the contents of the letter may be considered as a representative stance of the Catholic Church concerning the subject of gender. The letter was written in response to the emergence to various opinions voiced in the media by clerics and priests, concerning the subject of gender. As such, this document is part of a broader gender discourse and at the same time serves as the official stance of the Church leaders in public debate. The Catholic holiday - Feast of the Holy Family - became an opportunity to make their voice heard. The statement in the form of a pastoral letter, read during the Christmas period, reached a wide group of believers. The document was written on behalf of the "Shepherds of the Catholic Church in Poland" - the representatives of the Polish Episcopal Conference. ${ }^{1}$ The PEC encompasses the highest-ranked church leaders. ${ }^{2}$ The main objective, the Episcopal Conference is the joint resolution of "important matters, acting in a collegial spirit, in accordance with the nature of the Episcopate, for the benefit of the universal and particular Church." (Statute of the Polish Episcopal Conference..., Introduction). For the good of the Church, its leaders decided to address the issue of gender. Secondly, the document has triggered numerous reactions of the scientific and political communities. The stance adopted in the Letter was most widely commented on in the media and met with strong criticism not only from liberal and left-wing circles, but also from gender researchers.

1 "PEC is a permanent institution established by the Holy See, which consists of bishops canonically connected with the territory of the Republic of Poland, remaining in communion with the Bishop of Rome and fulfilling common pastoral tasks among the faithful in its territory under his authority, for the propagation of good by the service of the Church, especially by the forms of apostolate appropriately adapted to the circumstances of time and place, in accordance with the principles of universal law and the norms of this Statute." [KEP to stała instytucja utworzona przez Stolicę Apostolską, którą stanowią biskupi kanonicznie związani z terenem Rzeczpospolitej Polskiej, pozostający w jedności z Biskupem Rzymskim i pod jego autorytetem wypełniający wspólne pasterskie zadania wśród wiernych swojego terytorium dla pomnażania dobra przez posługę Kościoła, zwłaszcza przez formy apostolatu odpowiednio dostosowane do okoliczności czasu i miejsca, zgodnie z zasadami prawa powszechnego oraz normami niniejszego Statutu] (Statute of the Polish Episcopal Conference..., Chapter I, Article 1).

2 "These are: The Primate of Poland, who has honorary primate among Polish bishops; - Archbishops and diocesan bishops, as well as those who are almost equal to them; - Field bishop; - Bishops of the Byzantine-Ukrainian rite; - Coadjutor bishops; - Auxiliary bishops; - Bishops with titles who carry out special tasks within the Conference, assigned to them by the Holy See or the Polish Episcopal Conference." [A należą do nich: Prymas Polski, zachowujący honorowe pierwszeństwo wśród biskupów polskich; - Arcybiskupi i biskupi diecezjalni oraz ci, którzy są z nimi prawie zrównani; - Biskup polowy; - Biskupi obrządku bizantyjsko-ukraińskiego; - Biskupi koadiutorzy; Biskupi pomocniczy; - Biskupi tytułami pełniący w ramach Konferencji szczególne zadania, zlecone im przez Stolicę Apostolską lub Konferencją Episkopatu Polski] (Cf. Statute of the Polish Episcopal Conference..., Chapter I, Article 3). 
Since the stance on gender presented by the Church in the letter differs from scientific theory concerning this issue, it is appropriate to recall the most important assumptions of gender theory. The following discussion of the stance of the Catholic Church will include analyses of the manipulation techniques used by the authors of the letters, due to its persuasive character.

\section{Some comments on gender theory}

Gender is the subject of gender studies, a field of study derived from women's studies and feminist studies. The theory concerns culturally and socially shaped gender differences, assuming that, alongside biological gender, human identity is conditioned by many external factors affecting us in the processes of socialisation.

This field of study is slowly developing in Poland - we have more and more publications on gender issues, and some universities open post-graduate programmes and majors in gender studies. In 2014, a compendium on gender - a several-hundred-page-long book entitled Encyklopedia gender. Pteć w kulturze was published (Rudaś-Grodzka, 2014). ${ }^{3}$ The book presents gender studies to date in the form of various notions and concepts with explanations, encompassing numerous views and perspectives on gender issues, including a social, philosophical, literary, anthropological and linguistic perspective.

The number of specialised and comprehensive works on the issue of gender is sorely lacking. Most of the existing publications are post-conference, interdisciplinary studies and anthologies, as well as Polish translations of English-language texts. ${ }^{4}$ Polish researchers thus refer to the achievements of feminism and gender theory.

3 The concepts and notions included in the compendium of knowledge on gender were presented by researchers belonging to the Polish academic community, as well as people connected with feminist movements, working together in the Interdisciplinary Team for Literature and Gender Research at the Institute of Literary Research of the Polish Academy of Sciences. The editorial team, apart from Monika Rudaś-Grodzka, also included Katarzyna Nadana-Sokołowska, Agnieszka Mrozik, Kazimiera Szczuka, Katarzyna Czeczot, Barbara Smoleń, Anna Nasiłowska, Ewa Serafin, and Agnieszka Wróbel.

4 To date, gender studies in Poland were explored by researchers by Adam Buczkowski, Mariola Chomczyńska-Rubacha, Katarzyna Mirgos, Robert Ciborowski, Magdalena Dąbrowska, Elżbieta Durys, Inga Iwasiów, Michał Kanonowicz, Alicja Kuczyńska, Marian Machinek, Joanna Miluska, McDonald Miszczak, Joanna Mizielińska, Piotr Morciniec, Joanna Marczak, Eugenia Mandal, Dorota Pankowska, Ewa Głażewska, Anita Rawa-Kochanowska, Maria Strykowska, Tomasz Wojczak, who transplant the achievements of Western European and American researchers to the Polish academic environment. The model of Polish gender studies has not been developed to date, which is 
Despite these reservations, gender studies can be considered a scientific discipline, a well-developed theory, concepts and methodology. One element of gender research concerns considering gender in terms of opposition of the biological gender to the cultural one, as well as in terms of socio-cultural roles. Sources of these perspectives can be found in in feminist research and works, including Margaret Mead, Simone de Beauvoir, Robert Soller, Judith Butler, Kate Millet, Ana Oakley, Gale Rubin, Marija van Tillburg, and Joanna Scott. ${ }^{5}$

The opposition between biology and culture is a mainstay of gender studies. In 1949, Simone de Beauvoir stated that "One is not born, but rather becomes, a woman.” (after: Mizielińska, 2006: 44). The very word gender stands for cultural and social gender and is a particular model of masculinity and femininity in a given culture and society at a given time, as opposed to biological sex. A human being, who adopts a specific model, fulfils it in the form of a social role - male and female. Gender studies have gone one step further. Judith Butler, the pioneer of gender studies, extended the conceptual sphere by including gender identity. Gender identity refers to individual processing of sex and gender and identifying with a certain spectrum of male and female gender roles by an individual (see Butler, 2008).

The presented principles and assumptions of gender theory need to be further expanded by presenting its most important theoretical postulates. The original assumption of the theory was to bring about the notion of biological sex and gender, shaped at the same time by society and culture. In the light of gender theory, gender is perceived as an interpretation of sex and is present in culture and society as such a construct. With her research, Butler became a trailblazer of new interpretative paths.

According to Butler's gender performance theory, the category of gender is used in the ideological discourse of power, supported by the discourse of knowledge, which reinforce the image of the world based on the dichotomy of sex - the opposition of masculine and feminine. With that in mind, Butler posited that traditional discourses form a reality offering only two possibilities of playing social roles, a reality in which individuals adopt one of the two norms of sexuality and gender (Butler, 1995: 62; Wojczak, 2011: 21-23; Ciborowski, 2011: 7-8; Mizielińska, 2006: 7-19) According to gender scholars, by playing these roles, individuals build a world in which nearly all areas of human activity are created on the basis of

why I consider them attempts to continue Anglo-Saxon research, rather than setting new paths of interpretation.

5 The names of gender and identity researchers are mentioned in the majority of publications concerning this issue. 
heterosexual gender - from hierarchy of power, through public opinion, fashion and lifestyles, social communication, division of labour, to marriage and family models (Wojczak, 2011:21-23). Gender theorists recognise that in modern times, gender construed in this way legitimises power committed to the preservation of a traditional model of society. At the same time, this dichotomous nature of gender excludes individuals who do not want or cannot submit to traditional roles (see Ciborowski, 2011: 7-8; Mizielińska, 2006: 7-19).

Such an approach to gender - perception in terms of social role and cultural constructs, as well as examining sexuality (masculinity and femininity) as behaviours mediated by the society, is met with criticism of supporters of traditional model of society, including the Catholic Church. Although the proponents and supporters of religious discourse are more emotional in this "gender dispute" of sorts, the academic discourse on gender is not devoid of persuasion, either.

Butler (1995) as well as Polish gender researchers cover the idea of gender, as realised in social reality. The ideas of gender theory become the foundations for social change and transformative political concepts. They also serve as the basis for the activities of feminist activists and non-governmental organisations, who defend the rights of gender, sexual, ethnic, and other minorities. We may consider these practices as practical manifestations of the theory in reality.

Writing about gender, Emilia Kaczmarek pointed out that it is not only about the struggle for equal rights of women and men, but also about the idea of equality of women and men, as well as the idea of equality and individual freedom to form informal relationships and other actions. It is also an idea proclaiming tolerance towards people of different sexual orientations or non-traditional social roles. According to Kaczmarek, as a result, the idea of gender studies is the idea of freedom and equality of all individuals in society, with particular emphasis on different minorities, hence the inclusion of queer theory or multiculturalism in gender studies, which very often gives rise to attacks by people claiming that gender studies are concerned with the promotion of homosexuality (Kaczmarek, 2014). What is more, Kaczmarek confirms that a certain political strategy has been developed in the European Union, somewhat in parallel to the scientific theory, which focuses on taking measures to promote equality between women and men in political and social life. This concept is referred to as gender mainstreaming, serving as a way to integrate issues of gender studies into EU social policy. According to the researcher, this is a strategy implemented by means of equality policy, which is geared towards curbing marginalisation of women in the labour market, as well as exclusion of minorities, such as people with disabilities, homosexuals, ethnic minorities, etc. (Kaczmarek, 2014). 


\section{Presentation of the Pastoral Letter on the Feast of the Holy Family ${ }^{6}$}

The point of view of the Catholic Church on gender can be established on the basis of the analysis of this representative letter, which presents its beliefs. The authors of the letter clearly distance themselves from the gender theory and make a persuasive argument against it, by presenting their perspective on the issue of gender.

\section{Structure of the Letter}

The text has a form of a pastoral letter, and as such, it refers to homiletic, educational writings. This is indicated by a number of elements of its composition model. ${ }^{7}$ The metatextual character can be seen in the very title of the text - Pastoral Letter on the Feast of the Holy Family. Threats for family stemming from the gender ideology in the form of a headline, indicating the genre of the text.

Since the letter is intended to be read during Mass, it should be treated as a sermon. The paratextual element at the end of the letter reads that "The text is intended for pastoral use, in line with the decision of the diocesan bishop, on the Feast of the Holy Family, 29 December 2013".

The text comprises a framework characteristic of a pastoral letter. The initial component is a direct address to the faithful, a greeting" "Beloved in Christ! Sisters and Brothers!" and the final element of the letter is a greeting reminiscent of a blessing: "In this spirit, we give our pastoral blessing to all." Structure elements can therefore be divided into paratextual elements and main text.

The paratextual layer is made up of optional and obligatory elements. The optional elements include a statement specifying the purpose of the text and its intended use, sub-headings and confirmation of the conformity of the text ("For conformity: $\dagger$ Wojciech Polak, Secretary General of the Polish Episcopal Conference"). The objective of this statement is also to make the text credible and confirm its reliability. Mandatory elements include: title and subtitle, initial and final statements, as well as the signature of the authors of the letter (Signed: Pastors of the Catholic Church in Poland).

${ }^{6}$ In the text I refer to the longer version of the Pastoral Letter on the Feast of the Holy Family. See: Diocese of Łomża, Zagrożenia plynace $z$ ideologii gender (longer version), http://www.kuria. lomza.pl/index.php?wiad=4165, accessed: 18.04. 2015.

7 Maria Wojtak covered the issue of genres and religious messages, including sermons and pastoral letter. Cf. Wojtak, 2011; Wojtak, 1992: 90-97; Wojtak, 1998: 309-319; Wojtak, 2004a: 104-113; Wojtak, 2005: 577-597; Wojtak, 2007a: 429-442. 
The main text consists of an introduction, the main part, which is made up of three parts separated by sub-headings, as well as a conclusion. The introduction to the letter presents the subject matter of the text, including a reference to the nature and specificity of the holiday - Feast of the Holy Family, as well as to the main subject, which is the situation of the contemporary family.

In the first part we learn what gender ideology is and what are its dangers. The second part deals with the areas of social life in which gender ideology is introduced. The third part is an attempt to diagnose the phenomenon of gender and to indicate methods of fighting this ideology. The conclusion of the letter is a plea for prayer for married couples, families and children.

\section{The persuasive aspect of the Letter}

The authors play different illocutive roles, ${ }^{8}$ using the so-called author's self. They inform, and at some point, they become a preacher, teaching people in the name of the Christian faith. The letter reads:

The Christian vision reveals the deepest, innate meaning of marriage and family. The rejection of this vision inevitably leads to the breakdown of families and failure of human beings. As human history shows, disregarding the Lord has always been dangerous and threatens the happy future of humanity and the world. ${ }^{9}$

The role of the preacher is combined with that of a teacher or even a scientist who describes and studies certain scientific theories. In this case, the scientist analyses and discusses the gender ideology, shows its fallacies and confronts it with the principles of the Christian faith. By embedding this ideology in a social and cultural context, the authors take on another role, the role of an observer of social and public life. They become commentators, taking part in the public debate on gender.

Let us now examine excerpts and statements that expose the above-mentioned roles played by the author's self. In the first paragraph of the introduction to the Letter, the author-preacher introduces the recipient to the subject matter of the letter, talks about the circumstances of the Feast of the Holy Family, which led to

${ }^{8}$ Maria Wojtak wrote about the illocutive roles as the transformations of the author in a communication situation. See: Wojtak, 2004b. The researcher touches upon the problem of the author's self in relation to the author of generically blurred texts, adapting elements of other texts, including texts on the borderlines of other texts, as well as stylised texts.

9 „Chrześcijańska wizja objawia najgłębszy, wewnętrzny sens małżeństwa i rodziny. Odrzucanie tej wizji prowadzi nieuchronnie do rozkładu rodzin i do klęski człowieka. Jak pokazuje historia ludzkości, lekceważenie Stwórcy jest zawsze niebezpieczne i zagraża szczęśliwej przyszłości człowieka i świata”. 
undertaking such a subject. The following paragraphs are maintained in a similar tone. They speak of a Christian vision of marriage and family. The preacher refers to the social teachings of Pope John Paul II. From the fourth paragraph, we may observe a change in the role of the author's self. They become an observer of public life, commentator and defender of Christian principles:

It is understandable, therefore, that we need to be extremely concerned about the attempts to change the notion of marriage and family, which are being promoted these days, in particular by the proponents of gender ideology, and publicised by the media. In view of the mounting attacks on various areas of family and social life, we feel urged, on the one hand, to speak out firmly and unequivocally in defence of marriage and the family - the fundamental values that safeguard them, and, on the other, to warn against the dangers of promoting their new vision. ${ }^{10}$

The following parts of the text showcase a transition into the role of a scientist and researcher. By defending the principles of the Catholic faith, they defend the interests of the Church. In the first part of the main text of the letter, entitled The definition and dangers of the gender ideology, the author-scientist first defines the concept of gender ideology and then characterises its main features, manifestations and resulting threats. In the second part, Areas where gender ideology is introduced, the author's self becomes an expert in gender ideology, presenting methodologies employed by gender ideologues in various areas of social life. The last part of the main text is presented by a complex author, who remains an expert in the field of gender ideology, but also becomes an educator, who points to the ways of fighting this ideology, as well as a defender of the Christian faith and the Polish family against a hostile ideology.

In the global content analysis it can be noted that the implicitly expressed and dominant role of the author is that of an investigator, detective, accuser and judge. The author's "self" takes a closer look at contemporary society and looks for the manifestations of gender ideology to showcase its threats and its destructive character. They also put forward a number of arguments against the supporters of this ideology, including more and less detailed accusations, claiming that they intend to cause general demoralisation of society in all areas of public life. The Polish fam-

10 “Zrozumiałe jest zatem, że muszą budzić nasz najwyższy niepokój również próby zmiany pojęcia małżeństwa i rodziny narzucane współcześnie, zwłaszcza przez zwolenników ideologii gender (czyt. dżender) i nagłaśniane przez media. Wobec nasilających się ataków skierowanych na różne obszary życia rodzinnego i społecznego czujemy się przynagleni, by z jednej strony stanowczo i jednoznacznie wypowiedzieć się w obronie małżeństwa i rodziny, fundamentalnych wartości, które je chronią, a z drugiej przestrzec przed zagrożeniami płynącymi z propagowania ich nowej wizji." 
ily, which is a basic social unit, is particularly threatened by the spread of this ideology. After the accusations, a sentence is passed. The author states that this hostile ideology must be destroyed, and therefore makes an appeal to representatives of religious movements and ecclesiastical associations, parents, teachers, educational communities and all believers.

In the case of the analysed letter, the roles of a preacher, teacher, commentator, polemicist, judge and so on, can be summed up as a single role - a mentor, a person showing the way, presenting what is right and what is wrong, a kind of a life coach. In the life of believers, such a role is played by a priest, who serves as the link between the faithful and God. In religious messages, the author and the recipient have specific roles that are recognised and accepted in society. The faithful know their position in the communication hierarchy and even expects to be taught by a spiritual mentor. The time and place of communication is defined in advance for example mass; form of communication - pastoral letter; substance - spoken, as well as written (the letter is intended to be read and has the characteristics of the written and spoken variety of language); as well as subject matter - religion. ${ }^{11}$

A change in the illocutive roles changes the style of the Letter. The main text combines two styles - scientific (illocutive role of a scientist or researcher), as well as religious one (the role of a mentor, spiritual guide).

The scientific style dominates throughout the letter. These fragments take on the character of a monologue diagnosis and analysis of the gender ideology. Thus, we can see a short introduction, definition of the problem and the overarching thesis - Threats for family stemming from the gender ideology; an introduction to the issue, featuring a definition of gender, its features, a presentation of the problem, an attempt to defend the thesis with arguments and the effects of the introduction of gender ideology. Scientific terms such as gender ideology, gender, cultural gender, gender studies and more are scattered around in the text. The letter brings forth the issues of homosexuality, abortion, sexual education, as well as phenomena such as sexualisation, demoralisation and others. Thus, issues and problems of cultural, sociological, philosophical or psychological nature, are presented and showcased in the text.

The parts of the text written in religious style are distinguished by the vocabulary characteristic of church documents and writings, including the Charter of Family Rights, as well as publications and texts by Pope John Paul II (paragraphs

${ }^{11}$ Maria Wojtak covered the issue of specificity of religious communication, religious discourse, genres and religious messages, including sermons and pastoral letters. See: Wojtak, 2007; 1992: 309319; 2004: 104-113. 
no. $2,3,16$ ). The conclusion of the letter (paragraph no. 20) features a call or an appeal in the form of prayer of supplication, and in the introduction and paragraph no. 3 of the letter, the authors use the language characteristic of the teaching of the Church, including references to the Gospel, the teachings of Pope John Paul II and an explanation of contemporary phenomena in relation to these texts.

However, the employed style is more pseudo-scientific in nature. First of all, there is a marked lack of counter-arguments, sources of statements and opinions stated as truths. It is therefore a religious text - a pastoral letter, or a homily, featuring elements of a scientific text.

Throughout the entire letter, its authors refer to the dogmas of the Catholic faith, and appeal to the authority of Scripture, as well as personal authority of Pope John Paul II. This is not surprising given the nature of the document. The authors of the letter were somewhat doomed to choose this form of communication of their stance on gender. What is more, they take advantage of the fact that the recipients have little knowledge about the issue at hand. Furthermore, it is likely that the priests themselves, who have read the letter, have insufficient knowledge concerning this issue. This can be assumed from the hint for clergymen on how to read the word gender included in the text:

(...) we need to be extremely concerned about the attempts to change the notion of marriage and family, which are being promoted these days, in particular by the proponents of gender [read: jender] ideology, and publicised by the media. ${ }^{12}$

The fact that the author and the recipient have different levels of knowledge about the issue of gender makes the process of transmission and reception a topdown one. This makes it easier to manipulate the recipients. From a mentor's perspective, it is easier to control the faithful who are not aware of what gender is. The authors of the letter emphasise in a number of places that they describe phenomena concerning the society as a whole, which is, after all, diverse from the standpoint of religion and worldviews, including in statements such as:

The Church, which serves as the guardian of the good of every human being, has not only the right, but also the duty, to demand the natural rights of God to be upheld in social life. ${ }^{13}$

12 „(...) muszą budzić nasz najwyższy niepokój również próby zmiany pojęcia małżeństwa i rodziny narzucane współcześnie, zwłaszcza przez zwolenników ideologii gender (czyt. dżender) i nagłaśniane przez media”.

${ }^{13}$ „Kościół stojący na straży dobra każdego człowieka ma nie tylko prawo, ale i obowiązek upominać się o naturalne Prawa Boże w życiu społecznym". 
The statements urging the faithful not to succumb to the pressure of the socalled gender ideologues. such as:

We also appeal to the institutions responsible for Polish education not to give in to the pressure. We appeal to the representatives of religious movements and ecclesiastical associations to take bold action to disseminate the truth. ${ }^{14}$

take the form of advice.

Using their advantage, both in terms of knowledge and power, the church leaders play with the feelings of the faithful in a manipulative way. The authors of the letter appeal to authorities in order to reinforce their claims about gender ideology. In places where ecclesiastical authorities, such as the teachings of Pope John Paul II, the teachings of the Church and the Christian tradition are recalled and appealed to, the authors remind the faithful about the sinister and ideological nature of gender:

Let us ask the Holy Spirit to continue to give us the light of understanding, as well as seeing the dangers and threats facing the family and the Church today ... may not therefore keep silent in the light of attempts to introduce an ideology that is destructive to Christian anthropology ... We appeal to all believers to pray for marriages, families and children raised in them. In the face of gender ideology, it is an extremely important task to raise awareness of the dangers brought about by it, as well as to recall the fundamental and inalienable rights of the family. ${ }^{15}$

Christian faith and tradition are presented as ways to defeat gender. Gender ideology and its assumptions stand in opposition to the teachings of the Church. The authors also appeal to the authority of the former Pope and his teachings:

Blessed John Paul II, who will soon be canonised, reminds us that the truth about marriage is above the will of individuals, the whims of individual marriages, the decisions of social and governmental bodies. This truth should be sought from God, because "God Himself is the creator of marriage." 16

14 "Apelujemy także do instytucji odpowiadającym za polską edukacje, aby nie ulegały naciskom. Zwracamy się zatem z gorącym apelem do przedstawicieli ruchów religijnych i stowarzyszeń kościelnych, aby odważnie podejmowali działania, które będą służyć upowszechnianiu prawdy”.

15 "Prośmy Ducha Świętego, aby udzielał nam nieustannie światła rozumienia i dostrzegania niebezpieczeństw oraz zagrożeń, przed jakimi staje dziś rodzina/Kościół (...), nie może więc milczeć wobec prób wprowadzania ideologii niszczącej antropologię chrześcijańską (...). Wszystkich wierzących prosimy o żarliwą modlitwę w intencji małżeństw, rodzin oraz wychowywanych w nich dzieci/Wobec ideologii gender niezwykle ważnym zadaniem jest uświadamianie zagrożeń, które z niej płyną oraz przypominanie podstawowych i niezbywalnych praw rodziny.

${ }_{16}$ "Błogosławiony Jan Paweł II, do którego kanonizacji się przygotowujemy, przypomina, że prawda o małżeństwie jest ponad wolą jednostek, kaprysami poszczególnych małżeństw, decyzjami 
The references of the Polish Pope are significant in that he is not only a religious authority, but also a universally respected figure. ${ }^{17}$ In addition, the authors employ words that increase the prestige of the authority, valuing him positively, as well as the so-called authority of attributes - in this case, they use the attributes of religious holiness and sainthood, including terms and notions such as blessed, canonised.

One may also notice the authority of the book and the faith. The dogmas of faith and the teachings of the Scripture are referred to in a homiletic way:

It was God who created humans - man and woman, making them an irreplaceable gift for himself. He based the family on the foundation of a marriage, united for life by inseparable and exclusive love. The Christian vision reveals the deepest, innate meaning of marriage and family. The rejection of this vision inevitably leads to the breakdown of families and failure of human beings. ${ }^{18}$

The world is shown through the prism of the teachings of the Church. The authors of the Letter thus become an authority for the recipient, proclaiming their views in the form of a statement, which they claim to be the truth:

As human history shows, disregarding the Lord has always been dangerous and threatens the happy future of humanity and the world. Ignoring God's will in the family leads to the weakening of the bonds between is members. It also results in the spouses' reluctance to accept the gift of life, which results in negative demographic consequences. We are concerned by the fact that there is a growing social acceptance of these phenomena. ${ }^{19}$

Recalling authorities, who are important to the faithful, putting oneself in the position of authority and putting these authorities in opposition to gender is sup-

organizmów społecznych i rządowych. Prawdy tej należy szukać u Boga, ponieważ «sam Bóg jest twórcą małżeństwa»".

17 This is based on the study by Anna Grzywa. Cf. Grzywa, 1997. A persuasive author creates the appearance of professionalism of their statements, appealing to authority to make them seem credible. This authority may include people (generally respected individuals or loved ones), certain ways of speaking, languages and dialects, views deeply rooted by the society, cultural traditions, scientific theories, institutions, professions, quotes, books, and so on.

18 "To Bóg stworzył człowieka mężczyzną i kobietą, czyniąc ich niezastąpionym dla siebie darem. Rodzinę oparł na fundamencie małżeństwa złączonego na całe życie miłością nierozerwalną i wyłączną. Chrześcijańska wizja objawia najgłębszy, wewnętrzny sens małżeństwa i rodziny. Odrzucanie tej wizji prowadzi nieuchronnie do rozkładu rodzin i do klęski człowieka."

19 "Jak pokazuje historia ludzkości, lekceważenie Stwórcy jest zawsze niebezpieczne i zagraża szczęśliwej przyszłości człowieka i świata. Nieliczenie się z wolą Boga w rodzinie prowadzi do osłabienia więzi jej członków. Odnoszą się do własnych obserwacji, wiedzy: Powoduje też brak otwarcia się małżonków na dar życia, czego owocem są negatywne demograficzne skutki. Z niepokojem obserwujemy coraz większe przyzwolenie społeczne na te zjawiska." 
posed to convince the recipient that it is the Church who builds and fights for human welfare, security and social order. Gender supporters are people of low prestige, who are not concerned by the welfare of family and marriage. ${ }^{20}$

The entire argument represents the vantage point of the Church. The author and the recipient share a common system of values, the same worldview, which facilitates persuasion (Pisarek, 1976: 38-39). ${ }^{21}$ The authors make an attempt to convince the recipients by appealing to the will and feelings, using emotions (Pisarek, 1976: 40-41). ${ }^{22}$ The recipient may not deny the values (Christian values in this case) which they profess themselves, nor will they defend the values standing in opposition to them.

What is more, the narrative of the text uses first person, with elements of third-person perspective, ${ }^{23}$ which is supposed to reassure the recipient that the presented perspective is valid and proper. The first-person narrative dominates the parts of the text that speak about the traditional and Christian model of family and marriage, as well as appeals to the faithful. In this way, the authors create a community of the faithful. To a certain extent, the recipient becomes the author. There are numerous plural pronouns and verbs in first person, supported by great quantifiers and modal verbs, such as: we are experiencing, let us pray, we are preparing, we need to be extremely concerned, we are meeting, we appeal, we appeal to all believers. They also use collective terms: all believers, Poles, Families. These forms present a collective author - the Church leaders - but also show that the authors speak on behalf of all believers, thus uniting the faithful around the common cause - the fight against hostile ideology. The author points to the existence of an identification of the faithful with the Church. They also remind the faithful about the need of belonging to a community, of safeguarding the principles of faith and defending them against the gender ideology.

Gender ideology is the main concept presented in the Letter, brought up in a number of places. The main title of the Letter (Threats for family stemming from

${ }^{20}$ In his publication Język stuży propagandzie, Pisarek wrote about the manipulative use of authority. Those who manipulate link their activities with concepts that enjoy high social prestige and transpose well-established values to their own world. The activity of the opponent is linked to people and notions, which are not considered prestigious by the recipient.

${ }^{21}$ Pisarek claimed that elements of the text such as its author and recipient, the relationship between the two, the subject matter of the text and the mode of communication are obviously persuasive.

${ }^{22}$ Pisarek covered the manipulative use of the method of emotional persuasion, especially when it dominates over the method of rational persuasion.

${ }^{23}$ Pisarek wrote about primary persuasive linguistic means, distinguishing, among others, elements on lexical, syntactic and inflectional levels. 
the gender ideology. Pastoral Letter on the Feast of the Holy Family) has an informative but also persuasive function. Gender is considered to be an ideology, and this ideology is said to be dangerous for the family. The sub-headings of the Letter also bring up the ideological nature of gender and its dangerous character for the family. The authors of the letter state: The definition and dangers of the gender ideology. Despite its open-ended nature, this statement contains the answer, expressed in the second part, assuming that the gender ideology is something dangerous, since the dangers are mentioned right there in the text. The sub-headings are also persuasive in nature: Areas where gender ideology is introduced What to do against gender ideology? They contain pragmatic presuppositions. After assuming that gender is a dangerous ideology, the authors assume its presence in social life and suggest ways to curb and get rid of this ideology. The questions contain persuasive appeals. The authors directly state that gender is an ideology and convince us of its sinister nature.

According to the authors of the Letter, the supporters of gender ideology express social consent to negative phenomena, and the attacks of this ideology, including promoting the alleged new vision of marriage and family are a reason to defend fundamental values (referred to in paragraph no. 4). There is a brief description of gender, which is defined as utopian visions of marriage and family. The definition of gender is developed in paragraphs no. 6, 7, 8, however, the part containing the definition includes a number of labels and evaluations. Such opinions make it unnecessary for the recipient to draw conclusions or undertake any cognitive activity. This is particularly effective in the case of a recipient with little knowledge of gender. The language label that constitutes its definition is ideology. This word serves as an evaluation the concept of gender as a whole, because it is pejorative in its meaning. It is associated with manipulation, propaganda, demagogy, populism. Pisarek claimed that the notion of ideology has political connotations, and belongs to the political vocabulary of socialist and post-socialist countries (Pisarek, 1976: 6). The persuasive characteristics of ideology and the manipulation, demagogy or propaganda connected with it should be linked with its historical context. The language characteristic of ideology was newspeak - the language of power and the party, ${ }^{24}$ which also brings negative associations, stemming from socialist history.

${ }^{24}$ The issue of newspeak in socialism and in contemporary world was covered by numerous authors, including: S. Jadwiga, "Nowomowa - język naszych czasów," Poradnik językowy, no. 6, 1985; J. Bralczyk, "O języku polskiej propagandy politycznej”, [in:] Polszczyzna współczesna, Warszawa 1981; J. Bralczyk, "Strategie w języku polityki (O polskiej propagandzie w latach 1982-1988)”, [in:] O języku propagandy politycznej lat 80. i 90., J Bralczyk (ed.), Warszawa, 1999; M. Głowiński, "Dramat języka", [in:] Nowomowa i ciagi dalsze. Szkice dawne i nowe, Krakow, 2009; "Czy totalitaryzacja 
Even these days, ideology is perceived negatively when it is associated with imposing a different vantage point, and promoting it is persuasive by its very nature, since it leads to its implementation. ${ }^{25}$

Two possible schemes of defining gender as an ideology can be derived from the text:

(Notion X - definiendum) Gender is an ideology (Y - definiens).

Defined as ideology, the concept of gender is subsequently presented in more detail:

(Notion X - definiendum) Gender ideology is "something evil" (Y - definiens), for example enemy of family, enemy of marriage.

Paragraph no. 6 further expands on this definition, there, we find an explanation that gender ideology is:

The effect of ideological and cultural changes, strongly rooted in Marxism and neo-Marxism, promoted by increasingly radicalising feminist movements and the sexual revolution. ${ }^{26}$

The principles promoted by this ideology stand in direct opposition to reality and the traditional understanding of human nature. In addition, the authors believe that, according to the gender ideology, biological sex is only a cultural concept and can be chosen over time, while traditional family is a thing of the past and a burden on society. These are observations that are difficult to verify. The authors generalise and present information in a selective manner. They do not bring up the definition of gender theory, they do not mention the authors of the statements they quote. What is more important, they lie by equating biological sex to cultural gender,

języka?" [in:] Nowomowa i ciagi dalsze. Szkice dawne i nowe, Kraków 2009; D. Kępa-Figura, "Ideologizacja i „deideologizacja” komunikacji medialnej”, [in:] Oblicza komunikacji II - Ideologie w słowach i obrazach, Irena Kamińska-Szmaj, Tomasz Piekot, Marcin Poprawa (eds.), Wrocław 2008.

25 This issue was covered by E. Laskowska, among many others. Ideology as a collection of views, which do not have to be necessarily related to politics, encompasses ideas, as well as political, social, legal, ethical, religious, philosophical concepts and notions of an individual or group in a specific place, time and social circumstances. These views are relatively systematic, and they constitute a defined point of view which cannot be directly verified, but which may possibly be verified. Ideology can be mediated by political parties, religious associations, pressure groups or individuals. The researcher distinguished three levels of ideological message: Ideational, interactive and metadiscursive. The function of the ideological message is to encourage (axiological persuasion) and obligate. See: M. Laskowska,"Językowe wykładniki ideologii," [in:] Oblicza komunikacji. Perspektywy badań nad tekstem, dyskursem i komunikacja, I. Kamińska-Szmaj, Tomasz Piekot, M. Zaśko-Zielińska (eds.), Kraków, 2006.

${ }^{26}$ Efekt przemian ideowo-kulturowych, mocno zakorzenionych w marksizmie i neomarksizmie, promowanych przez coraz bardziej radykalizujące się ruchy feministyczne oraz rewolucję seksualną. 
since they omit the category of the opposition of the biological sex and gender. In the light of gender theory, gender is considered to be an interpretation of biological sex, not its equivalent.

One can also note evaluating ${ }^{27}$ labels, which are supposed to have pejorative connotations, by unequivocally associating gender with sinister ideology. The letter contains both directly evaluating words, presenting evaluation on the spectrum of good and evil, including: enemy, evil, as well as indirect evaluation through the use of expressions referring to phenomena that are usually assessed negatively by the majority of conservative society, such as homosexual propaganda, sex change. Gender is thus equated to Marxism, neo-Marxism, feminist movements, sexual revolution, homosexuality, abortion, in vitro fertilisation, sex change - concepts, which carry values inconsistent with the vision of the world presented by the Church.

Gender ideology is the effect of decades of ideological and cultural changes, strongly rooted in Marxism and neo-Marxism, promoted by increasingly radicalising feminist movements and the sexual revolution, which started in 1968. Gender promotes principles that stand in direct opposition to reality and the traditional understanding of human nature. ${ }^{28}$

The ideological and cultural transformations in the spirit of gender are presented as anti-values, standing in opposition to reality, not only Catholic one.

The authors of the Letter define the concept of gender. They, however, never directly conflate gender with cultural gender. However, they write about cultural gender as the most radical form of gender ideology. They remind the believers that gender ideologues negate the biological sex, which is an example of nature's violence against human beings. According to the authors of the Letter, gender is supposed to be apparent only in external behaviours. Again, we are seeing unverifiable and generalised claims. For example, the perspective of gender as a social role is disregarded. The authors also quote short excerpts from Judith Butler's theory. When writing about gender as the most radical form, they quote claims that: Human beings become entangled in gender, and that they gain true, unrestricted freedom. The

${ }^{27}$ Polish researchers covering the issue of linguistic axiology include Jadwiga Puzynina and Jerzy Bartmiński. The values in politics were studied by academics working as part of the Lublin School of Ethnolinguistics: J. Bartmiński, I. Bielińska-Gardziel, J. Szadura, M. Brzozowska, I. Lappo, S. Niebrzegowska-Bartmińska, B. Żywicka, R. Tokarski. See: J. Puzynina, Słowo-wartość-kultura, Lublin 1997; Język, wartości, polityka. Zmiany rozumienia nazw wartości w okresie transformacji ustrojowej w Polsce. Raport z badań empirycznych, J. Bartmiński (ed.), Lublin, 2006.

28 "Ideologia gender stanowi efekt trwających od dziesięcioleci przemian ideowo-kulturowych, mocno zakorzenionych w marksizmie i neomarksizmie, promowanych przez coraz bardziej radykalizujące się ruchy feministyczne oraz rewolucję seksualną zapoczątkowaną w 1968 roku. Gender promuje zasady całkowicie sprzeczne z rzeczywistością i tradycyjnym pojmowaniem natury człowieka.” 
fact that gender is supposed to be based only on internal characteristics means that a person has the right to spontaneously change their already made choices and choose one of the five genders, which include gay, lesbian, bisexual, transsexual and heterosexual gender. There is no such gender classification in gender theory, and thus the authors mix up gender identities with sexual orientations. They also mix the concepts of gender, biological sex, sexuality, gender identity and the sense of gender identity. In the following sections, these categories are already referred to as non-stereotypical sexual roles - this concerns transsexualism and homosexuality.

The text is a collection of evaluating concepts and words geared towards creating a sense of threat - non-stereotypical sexual roles, homosexual propaganda, the obligation to educate and promote homosexuality and transsexualism.

What is stereotypical is valued positively and denotes something desirable, expected by the target recipient (the faithful, believers attending the Church), and at the same time something safe, because it is already known in a specific reality (the Catholic world). Stereotypical sexual roles are the traditional, heterosexual roles. Everything that steps away from the stereotype is perceived to be negative. Non-stereotypical sexual roles are supposed to be never expected by the recipient of the Letter, but also unknown and strange, and the Letter presents them as destructive. Positive evaluation of what is stereotypical gives rise to prejudices against that, which is non-stereotypical, such as non-stereotypical sexual roles - homosexuality and transsexualism, ${ }^{29}$ which are said to be promoted by gender ideologues. The words promotion, like the homosexual propaganda, are not used here by accident. According to Pisarek, "these days, the word propaganda is considered too discredited to be suitable for neutral use." (Pisarek, 1976: 5-6). ${ }^{30}$ Like "manipulation" or "demagogy", the notion carries a number of negative connotations. Propaganda character is attributed to the actions of the opponent - for example like in the case of notions such as sinister propaganda, bourgeois propaganda (Pisarek, 1976). Propaganda, just like manipulation, persuasion, demagogy, promotion or provocation are activities based on the principle of influencing human attitudes and behav-

${ }^{29}$ Creating and disseminating stereotypical concepts, expressions and stereotypical thinking is one of the principles of persuasive tactics. See: Pisarek, 1976: 43. Jerzy Bartmiński claimed that stereotypes include positive or negative evaluation of a given object in reality. The vantage point shaped by stereotypes has an impact on construing the stereotypical image of the world, which is subjective. Objective knowledge is modified by the collective consciousness of a given community in accordance with its system of norms and values. Stereotypes are linked to actions and behaviours, stimulate attitudes and encourage specific behaviours. See: Bartmiński, Panasiuk, 2001: 375-382, 393-394.

${ }^{30}$ The notion of propaganda continues to carry the meaning of of strongly ideological, unfair actions, linked in particular with the public sphere and politics. See also: Kępa-Figura, Nowak, 2000. 
iours. Very often these actions are unfair, or simply perceived as such (see Puzynina, 1985; 1992; Kamińska-Szmaj, 2004).

The author uses information which are difficult or impossible to prove, providing only generalised information. The sinister nature of this ideology is to be found in the references to various documents; which are mostly imprecise. There is no mention of their content, except for their generally destructive nature. However, the Letter covers the intended purpose of these documents:

One of the examples is the Council of Europe Convention on preventing and combating violence against women and domestic violence, which - although devoted to the significant problem of violence against women - nevertheless promotes the so-called "non-stereotypical sexual roles" and deeply interferes with the educational system by imposing an obligation to educate in and promote homosexuality and transsexualism, among others. ${ }^{31}$

The information provided in this excerpt is difficult to verify. There are no quotes from the documents in question. The names of documents and examples of their implementation are matched to general and anecdotal statements.

In the last six months, there was even a draft of the so-called "Equality Act," which broadened the list of categories protected against discrimination, by including "gender identity and expression." The adoption of the draft consequently restricts freedom of speech and the expression of religious beliefs. ${ }^{32}$

These are subjective interpretations by the authors of the Letter. Before the law enters into force, its actual impact may only be assumed. It seems unreasonable to conflate the prohibition of discrimination on grounds of gender identity and gender expression, with restrictions of freedom of speech and expression:

Anyone who dares to criticise homosexual propaganda in future will be subject to criminal penalties. This also poses a threat to the functioning of Catholic media and, in fact, assumes the need for self-censorship. ${ }^{33}$

31 "Przykładem jest Konwencja Rady Europy przeciwko przemocy wobec kobiet, która, choć poświęcona istotnemu problemowi przemocy wobec kobiet, promuje jednak tzw. «niestereotypowe role seksualne» oraz głęboko ingeruje w system wychowawczy nakładając obowiązek edukacji i promowania, między innymi homoseksualizmu i transseksualizmu."

32 "W ostatnim półroczu powstał nawet projekt tzw. ustawy «równościowej» poszerzającej katalog zakazu dyskryminacji, między innymi ze względu na «tożsamość i ekspresję płciową» Przyjęcie projektu ogranicza w konsekwencji wolność słowa i możliwość wyrażania poglądów religijnych.”

33 "Ktokolwiek w przyszłości ośmieli się skrytykować propagandę homoseksualną, będzie narażony na konsekwencje karne. Stanowi to zagrożenie także dla funkcjonowania mediów katolickich oraz zakłada właściwie konieczność wprowadzenia autocenzury." 
It is suggested that gender studies educate future gender ideologues. There are claims that according to gender, the family is a thing of the past and does not matter:

They are used to educate new ideologues, claiming that family is a thing of the past and that it does not matter whether a child is raised by gays or lesbians, because it is just as happy in such structures and develops just as well as a child raised in a traditional family. ${ }^{34}$

The gender theory concerns the existence of various family models, not the end of the concept of family altogether.

The following passages contain more information that is difficult to verify, concerning suicidal tendencies, identity disorders, depression and sexual harassment in homosexual families raising children. The authors refer to unspecified research results on this subject:

However, the results of the studies, which indicate negative or even tragic consequences for the lives of people growing up in such environments: suicidal tendencies, identity disorders, depression, sexual harassment or exploitation, are disregarded. ${ }^{35}$

The recipients have no idea about the authors of the studies or even the study in question. The descriptions of gender ideology impose evaluations of neutral facts concerning gender theory, twisting the meaning of said theory, coming up with unfounded claims, mainly concerning worldviews, in order to impact the imagination of the recipient. The author states unverifiable assessments without providing sources or data:

According to its ideologues, the content of films, popular TV series, plays, television broadcasts and exhibitions, includes figures and images geared towards changing social awareness to the adoption of gender ideology, added using the latest manipulation techniques. ${ }^{36}$

34 „Kształci się na nich nowych propagatorów tej ideologii i głosi, że rodzina jest już przeżytkiem i nie ma znaczenia, czy dziecko jest wychowywane przez gejów czy lesbijki, bo jest w takich strukturach równie szczęśliwe, rozwijając się tak samo dobrze, jak dziecko wychowywane w tradycyjnej rodzinie".

35 „Przemilcza się natomiast badania, których wyniki wskazują na negatywne czy wręcz tragiczne skutki w życiu osób wzrastających w tego typu środowiskach: na tendencje samobójcze, zaburzenia w poczuciu tożsamości, depresje, wykorzystywanie seksualne czy molestowanie".

${ }^{36}$ „Zgodnie z założeniami jej ideologów, w treści filmów, popularnych seriali, sztuk teatralnych, programów telewizyjnych, czy wystaw, są włączone - przy wykorzystaniu najnowszych technik manipulacyjnych - postacie i obrazy służące zmianie świadomości społecznej w kierunku przyjęcia ideologii gender." 
However, the authors do not specify which manipulation techniques were involved, let alone which products of culture are concerned. Who are these characters? What are these images geared towards changing social awareness? Another far-reaching generalisation, not supported by any evidence, is the statement that gender aims at sex education - They very cleverly overlook the fact that the aim of gender education is essentially sexualisation of children and youth, which contributes to the sexualisation of children and youth: However, awakening sexuality from an early age leads to addictions in the sexual sphere, which later in life can lead to the enslavement of the human being. The apparent sexualisation is supposed to lead to sexual addictions, also known as sexual enslavement, including rape, paedophilia, sexual violence, but also other addictions, such as drug addiction and alcoholism. All of this is conducive to dismantling the family.

These allegations were not supported by evidence and cannot be verified as such. The use of evaluations of gender ideology as its description objectivises subjective messages. In listing the potential effects of the gender ideology (sexualisation, demoralisation, dismantling of family), the authors refer to the future, which also constitutes unverifiable information. They also saturate the text with many pejorative terms. These phenomena are evaluated negatively not only by the Church, but also socially criticised. Sexual violence is a violation of the law, and as such, it is illegal. All listed addictions require treatment. However, in this case, they are manipulatively included in sex education, which is directly associated with gender.

The whole letter also uses genre styling in a manipulative manner. The change of style from religious to scientific serves the purpose of changing the communication roles of the author. As we already mentioned, in order to make their postulates credible, the author plays the role of a spiritual guide, guardian of the Christian world, as well as a scientist who exposes the enemy - gender ideology. This results in the presence of stylistic elements from different discourses.

\section{Final conclusions}

The Pastoral Letter on the Feast of the Holy Family. Threats for Family Stemming from the Gender Ideology has the characteristics of a preacher's text. The topic, associated with the occasion - family issues, as well as the intended use for the letter to be read on the Feast of Holy Family, is only a pretext for discussing gender ideology.

According to the analysed genre - sermon - the persuasive function is dominant in the Letter, which is supposed to persuade the recipient to adopt the same 
assumptions as the authors concerning gender, This function is to be carried out by means of appeals, excessive presentation of the author's self, building their image as an authority, getting closer to the recipient through direct addresses, using the biblical language, as well as uniting the recipients in opposition of a common threat or enemy.

At the same time, the religious vantage point is mixed with the scientific point of view. The analysed text is a statement with some characteristic features of a proclamation, a political appeal. The scientific category is transposed into the sphere of political and social ideology. The notion of gender is being redefined; thus, the original meaning of gender category is manipulated, giving rise to a new construct with a brand-new meaning. Gender is presented as one of the most important problems of public life, appearing in this text as a threat to the existing system of organisation of social space and a dangerous ideology, which may usher in a cultural, moral and political revolution, whose origins lie in deadly ideologies such as: Bolshevism, Nazism and communism. In this context, the letter presenting gender as an ideology is thus included in the ideological and political dispute concerning gender.

Throughout the letter, one may notice the use of the vantage point category for persuasive purposes, ${ }^{37}$ which is facilitated by the fact that both the author and the recipient share the same system of values. ${ }^{38}$ From a specific (ecclesiastical) vantage point, the image of the world is manipulated, the characteristics of the perceived object (gender) are selected and evaluated in a specific manner (in line with the teachings of the Church), thus giving rise to a subjective vision of the world. Although the vision is consistent with the system of values, it is - in many aspects false. As a result of the manipulative techniques used, the vantage point of the Church was presented as the universal point of view of every human being, not

37 The notion of vantage point is particularly linked with various areas of human activity, connected with the pursuit of knowledge of truth, including the spheres of culture, history and politics. Hence the presence of a category of a vantage point in public discourses, where aesthetic, ethical, hedonistic values, as well as political measures aimed at defending particular and group interests play an important - often essential - role. Numerous studies on the vantage point and methods of profiling are conducted by the Lublin community of ethno-linguists. See: Bartmiński, 1991; 1993; 1999; Bartmiński, Tokarski, 1986; Bartmiński, Niebrzegowska, 1998; Bartmiński, Niebrzegowska-Bartmińska, 2004.

38 The convergence of the vision of the author's world and the vision of the recipient's world, the convergence of their vantage points points to the emotional and intellectual closeness of the author and the recipient - a cultural unity, and thus the linguistic measures used by the author are accepted by the recipient. This facilitates the process of manipulation. See: Tokarski, 2004. 
only those who profess Catholic faith. ${ }^{39}$ The vantage point on gender presented by the Church refers to the positively perceived stereotype of a Catholic who adheres to traditional values and who - due to their experience (common to most Catholics), should be critical of gender. ${ }^{40}$

The right-wing and Church discourse is based on nationalist, patriotic and religious values, using Christian and conservative narratives. Gender is shown as the enemy of reality based on such values. Perhaps the aim of the originators of such a discourse was to identify an enemy. Perhaps defining a fictitious enemy was a way of diverting attention from the situation of internal crisis and the real problems of the Church.

The concept of gender, understood as cultural gender, has been falsified. The proposed explanations are in fact incomplete and stray away from expert knowledge, and as such, they are not confronted with scientific assumptions. The authors of the letter show that gender issues are politicised and ideological; however, they themselves are unable to escape the ideologisation of their own stance.

\section{Bibliography}

Bartmiński J. (1991), Punkt widzenia, perspektywa, językowy obraz świata, [in:] J. Bartmiński (ed.), Językowy obraz świata, Lublin.

Bartmiński J. (1993), O profilowaniu i profilach raz jeszcze, [in:] J. Bartmiński, R. Tokarski (eds.), O definicjach $i$ definiowaniu, Lublin.

Bartmiński J. (1999), Punkt widzenia, perspektywa, językowy obraz świata, [in:] J. Bartmiński (ed.), Językowy obraz świata, Lublin.

Bartmiński J., Niebrzegowska S. (1998), Profile a podmiotowa interpretacja świata, [in:] J. Bartmiński (ed.), Profilowanie w języku i w tekście, Lublin.

Bartmiński J., Niebrzegowska-Bartmińska S. (2004), Dynamika kategorii punktu widzenia w języku, tekście i dyskursie, [in:] J. Bartmińki, S. Niebrzegowska-Bartmińska, R. Nycz (eds.), Punkt widzenia w języku i w kulturze, Lublin.

${ }^{39}$ The use of vantage point for manipulation was covered by Elżbieta Tabakowska and Anna Rzepkowska. In the context of this study, the vantage point of the Church can be said to be conventionalised, universally accepted way of describing reality characteristic of a given community. The category of vantage point used for persuasion is therefore manifested not in specific language, but in the selection of language measures, their specific choice and their use in a specific context - like a pastoral letter, as presented in the example. See: Tabakowska, 2004: 53-54; Rzepkowska, 2004.

${ }^{40}$ The issue of religious vantage point was covered by Monika Zaśko-Zielińska. Theologically motivated discourses contain contradictory and specific scientific and theological vantage points, which are often manipulated by complementing them with common perspectives, religious fanaticism, quasi-religiousness, pseudo-science, strong emotions and stereotypes. See: Zaśko-Zielińska, 2004: 255-257. 
Bartmiński J., Panasiuk J. (2001), Stereotypy językowe, [in:] J. Bartmiński (ed.), Wspótczesny język polski, Lublin.

Bartmiński J., Tokarski R. (1986), Językowy obraz świata a spójność tekstu, [in:] T. Dobrzyńska (ed.), Teoria tekstu. Zbiór studiów, Wrocław.

Bralczyk J. (1981), O języku polskiej propagandy politycznej, [in:] H. Kurkowska (ed.), Współczesna polszczyzna. Wybór zagadnień, Warszawa.

Bralczyk J. (1999), Strategie w języku polityki (O polskiej propagandzie w latach 1982-1988), [in:] J. Bralczyk (red.), O języku propagandy politycznej lat 80. i 90., Warszawa.

Butler J. (1995), Podmioty płci/płciowość/pragnienia, Spotkania Feministyczne, Warszawa.

Butler J. (2008), Uwikłani w płeć. Feminizm i polityka tożsamości, trans. K. Krasuska, Warszawa.

Ciborowski R. (2011), O performatyce genderowej słów kilka, [in:] K. Mirgos (ed.), Płeć w kulturze, Wielichowo.

Głowiński M., (2009), Nowomowa i ciagi dalsze. Szkice dawne i nowe, Kraków.

Grzywa A. (1997), Manipulacja. Mechanizmy psychologiczne, Kraśnik.

Kaczmarek E. (2014), Co to właściwie jest ten dżender? Mały słownik dla genderowo zdezorientowanych,] http://kulturaliberalna.pl/2014/01/23/wlasciwie-dzender-maly-slownik-genderowozdezorientowanych/, accessed: 2.03.2014.

Kamińska-Szmaj I. (2004), Propaganda, perswazja, manipulacja - próba uporządkowania pojęć, [in:] P. Krzyżanowski, P. Nowak (eds.), Manipulacja w języku, Lublin.

Kępa-Figura D. (2008), Ideologizacja i „deideologizacja” komunikacji medialnej, [in:] I. Kamińska-Szmaj, T. Piekot, M. Poprawa (eds.), Oblicza komunikacji II - Ideologie w stowach i obrazach, Wrocław.

Kępa-Figura D., Nowak P. (2000), „Nowa epoka - stary język?” - środki perswazyjne przed i po zniesieniu cenzury, [in:] J. Adamowski (ed.), Środki masowej informacji w Polsce po likwidacji instytucji cenzury (1990-2000), Warszawa.

Laskowska M. (2006), Językowe wykładniki ideologii, [in:] I. Kamińska-Szmaj, T. Piekot, M. Zaśko-Zielińska (eds.), Oblicza komunikacji. Perspektywy badań nad tekstem, dyskursem i komunikacją, Kraków.

Mizielińska J. (2006), Płeć. Ciało. Seksualność. Od feminizmu do teorii queer, Kraków.

Pisarek W. (1976), Język stuży propagandzie, Kraków.

Puzynina J. (1985), O pojęciu „manipulacji” oraz sensie wyrażenia „manipulacja językowa”, [in:] Nowomowa. Materiały z sesji naukowej poświęconej problemowi wspótczesnego języka polskiego odbytej na UJ w dniach 16 i 17 stycznia 1981, Londyn.

Puzynina J. (1992), Słowo „manipulacja” w języku polskim, [in:] J. Puzynina, Język wartości, Warszawa. Puzynina J. (1997), Słowo - wartość - kultura, Lublin.

Puzynina J. (2006), Język, wartości, polityka. Zmiany rozumienia nazw wartości w okresie transformacji ustrojowej w Polsce. Raport z badań empirycznych, Lublin.

Rudaś-Grodzka M. (2014), Encyklopedia gender. Płeć w kulturze, Warszawa.

Rzepkowska A. (2004), Punkt widzenia i punkt obserwatora jako środki perswazji, [in:] J. Bartmiński, S. Niebrzegowska-Bartmińska, R. Nycz (eds.), Punkt widzenia w języku i w kulturze, Lublin.

Sambor J. (1985), Nowomowa - język naszych czasów, Poradnik Językowy, z. 6.

Statut Konferencji Episkopatu Polski z 7 X 2009 r., rozdz. I, art. 1: http://episkopat.pl/episkopat/ statut/4463.1,Statut_Konferencji_Episkopatu_Polski.html, accessed: 2.03.2014.

Tabakowska E. (2004), O językowych wyznacznikach punktu widzenia, [in:] J. Bartmiński, S. Niebrzegowska-Bartmińska, R. Nycz (eds.), Punkt widzenia w języku i w kulturze, Lublin. 
Tokarski R. (2004), Manipulacja to zniewalanie. A cóż począć z „urodzonymi w niewoli”? [in:] P. Krzyżanowski, P. Nowak (eds.), Manipulacja w języku, Lublin.

Wojczak T. (2011), Gender w badaniach mediewistycznych, [in:] K. Mirgos (ed.), Płeć w kulturze, Gniezno.

Wojtak M. (1992), O początkach stylu religijnego w polszczyźnie, Stylistyka I, Opole.

Wojtak M. (1998), Czy można mówić o stylu człowieczej rozmowy z Panem Bogiem?, [in:] S. Gajda, H.J. Sobeczko (eds.), Człowiek - dzieło - sacrum, Opole.

Wojtak M. (2004a), Gatunki prasowe, Lublin.

Wojtak M. (2004b), Styl religijny w perspektywie genologicznej, [in:] S. Mikołajczak, T. Węcławski (eds.), Język religijny dawniej i dziś, Poznań.

Wojtak M. (2005), Gatunkowe wyznaczniki rytualizacji wypowiedzi, [in:] R. Zarębski (ed.), Rytuał język - religia. Materialy z konferencji 17-19 maja 2004 r., Łódź.

Wojtak M. (2007a), Genologiczne aspekty charakterystyki modlitewnika - zarys problematyki, Studia Językoznawcze vol. 4: Synchroniczne i diachroniczne aspekty badań polszczyzny, Szczecin.

Wojtak M. (2007b), Styl gatunku, styl gatunkowy a styl funkcjonalny w perspektywie analitycznej, [in:] D. Ostaszewska (ed.), Gatunki mowy i ich ewolucja, vol. III, Gatunek a odmiany funkcjonalne, Katowice.

Wojtak M. (2011), Współczesne modlitewniki w oczach językoznawcy. Studium genologiczne, Teolingwistyka t. 9, Tarnów.

Zagrożenia płynące $z$ ideologii gender, http://www.kuria.lomza.pl/index.php?wiad=4165, accessed: 18.04.2015.

Zaśko-Zielińska M. (2004), Sekta czy nowy ruch religijny: zderzenie poglądów, zderzenie punktów widzenia, [in:] J. Bartmiński, S. Niebrzegowska-Bartmińska, R. Nycz (eds.), Punkt widzenia w języku i w kulturze, Lublin. 